\title{
Effects of Salbutamol in Collagen like Tail Subunit of Asymmetric Acetylcholinesterase-Related Congenital Myasthenic Syndrome: A First Korean Case
}

\author{
Han Geul Kim, MD ${ }^{1}$ Jin Sung Lee, MD $D^{1,2}$, Kyung Won Kim, MD ${ }^{1,3}$, Hoon-Chul Kang, MD ${ }^{1,4}$, Se Hee Kim, MD \\ 'Department of Pediatrics, Severance Children's Hospital, Yonsei University College of Medicine, Seoul, Korea \\ ${ }^{2}$ Division of Clinical Genetics, Department of Pediatrics, Severance Children's Hospital, Yonsei University College of Medicine, Seoul, Korea \\ ${ }^{3}$ Division of Allergy and Respiratory Medicine, Department of Pediatrics, Severance Children's Hospital, Yonsei University College of \\ Medicine, Seoul, Korea \\ ${ }^{4}$ Division of Pediatric Neurology, Department of Pediatrics, Severance Children's Hospital, Yonsei University College of Medicine, Seoul, \\ Korea
}

Received: August 6, 2020

Revised: September 8, 2020

Accepted: September 24, 2020

Corresponding author:

Se Hee Kim, MD

Division of Pediatric Neurology,

Department of Pediatrics,

Severance Children's Hospital,

Yonsei University College of

Medicine, 50-1 Yonsei-ro,

Seodaemun-gu, Seoul 03722,

Korea

Tel: +82-2-2228-2050

Fax: +82-2-393-9118

E-mail: seheekim@yuhs.ac
The congenital myasthenic syndrome (CMS) is a heterogeneous group of disorders of the neuromuscular junction [1]. Suspecting and performing a molecular genetic testing is important in CMS considering that the symptoms in this group of disorders are similar, but treatments vary. The syndrome can be classified as presynaptic, synaptic basal lamina associated, and postsynaptic according to the location of the defects and genetic diagnosis [2]. Administration of acetylcholinesterase $(\mathrm{AChE})$ is often the treatment of choice, but caution is required because $\mathrm{AChE}$ can aggravate the symptoms in collagen like tail subunit of asymmetric acetylcholinesterase (COLQ)-related CMS (Table 1) [3-5]. Here, we report a first Korean female patient who was diagnosed with COLQ-related CMS with muscle disease gene panel.

A 2-year-old girl was transferred to the pediatric intensive care unit (PICU) of our hospital due to respiratory failure. This was her seventh admission to the PICU due to respiratory difficulty. At the age of 10 days, she developed paroxysmal cyanosis, poor oral intake, and decreased activity and was admitted to the other hospital for the first time due to respiratory failure without pathogen. At the age of 2, 4, 6, and 8 months, she was readmitted due to respiratory failure without pathogen. Only at the age of 11 months, she was admitted to the PICU due to respiratory syncytial virus infection.

On admission, she looked dysmorphic with myopathic face, high arched palate, midfacial hypoplasia and micrognathia. On physical examination, she had low body weight $(5.6 \mathrm{~kg},<3 \mathrm{rd}$ percentile), normal height $(70 \mathrm{~cm}, 77$ th percentile), and normal head circumference $(41.5 \mathrm{~cm}$, 24th percentile). Physical examination also showed shallow breathing, neck flexor weakness, and generalized proximal dominant motor weakness in both upper and lower extremity, though there were no scoliosis, apparent muscle atrophy, and contractures. However, on neurologic examination, she had a normal deep tendon reflex, and Babinski reflex was not observed.

Her development was delayed. She could sit without aid and crawl, but she could not independently walk at the age of 2 years and spoon

Copyright (C) 2021 Korean Child Neurology Society

This is an Open Access article distributed under the terms of the Creative Commons Attribution Non-Commercial License (http://creativecommons.org/licenses/by-nc/4.0/) which permits unrestricted non-commercial use, distribution, and reproduction in any medium, provided the original work is properly cited. 
Table 1. Summary of results of a few previous COLO-mutant congenital myasthenic syndrome studies

\begin{tabular}{|c|c|c|c|c|c|c|c|c|c|c|}
\hline \multirow{2}{*}{$\begin{array}{l}\text { Publication } \\
\text { year }\end{array}$} & \multirow{2}{*}{ Country } & \multirow{2}{*}{$\begin{array}{l}\text { No. of patients } \\
\text { with COLO }\end{array}$} & \multirow{2}{*}{$\begin{array}{l}\text { Mean age of onset/ } \\
\text { mean diagnostic age }\end{array}$} & \multirow{2}{*}{$\begin{array}{l}\text { Drugs received anytime during the whole course } \\
\text { of illness (dose) }\end{array}$} & \multicolumn{6}{|c|}{ Response to drugs (I/NR/W/-) } \\
\hline & & & & & $P$ & $\mathrm{~N}$ & $E$ & $\mathrm{D}$ & $S$ & A \\
\hline \multirow[t]{3}{*}{2012} & \multirow[t]{3}{*}{ Turkey } & \multirow[t]{3}{*}{4} & \multirow[t]{3}{*}{ At birth/6.6 yr } & $\begin{array}{l}\text { Pyridostigmine (orally } 2 \mathrm{mg} / \mathrm{kg} / \text { day in patient no. } 3 \\
\text { and 4) }\end{array}$ & NR & - & NR & I & I & I \\
\hline & & & & $\begin{array}{l}\text { 3,4-diaminopyridine (orally } 15 \text { to } 40 \mathrm{mg} / \text { day in } \\
\text { patient no. } 1,3 \text {, and } 4 \text { ) }\end{array}$ & & & & & & \\
\hline & & & & $\begin{array}{l}\text { Oral salbutamol (0.1 mg/kg/day in patient no. 2), } \\
\text { intravenous ephedrine }(0.5-1 \mathrm{mg} / \mathrm{kg} / \text { day in } \\
\text { patient nos. } 1 \text { and } 4) \text {, extended-release oral } \\
\text { albuterol (16 mg/day in patient no. 3) }\end{array}$ & & & & & & \\
\hline 2012 & France & 15 & $23.5 \mathrm{mo} / 23 \mathrm{yr}$ & $\begin{array}{l}\text { 3,4-diaminopyridine ( } 30 \text { to } 60 \mathrm{mg} / \text { day in } 8 \\
\text { patients), pyridostigmine (in } 11 \text { patients), } \\
\text { ephedrine (in } 3 \text { patients) }\end{array}$ & $\mathrm{NR} / \mathrm{W}$ & - & 1 & I & - & - \\
\hline 2015 & Canada & 2 & At birth/no data & Pyridostigmine, 3,4-diaminopyridine & $N R / I$ & - & - & I & - & - \\
\hline 2019 & Turkey & 5 & $8.7 \mathrm{mo} / 5.2 \mathrm{yr}$ & $\begin{array}{l}\text { Ephedrine (0.5-1 mg/kg/day), salbutamol (0.1 mg/ } \\
\text { kg/day) }\end{array}$ & - & - & I & - & I & - \\
\hline 2019 & India & 4 & $7.3 \mathrm{yr} / 13 \mathrm{yr}$ & $\begin{array}{l}\text { Salbutamol (5-10 mg/day), neostigmine(30-60 } \\
\text { mg/day in one patient) }\end{array}$ & - & W & - & - & I & - \\
\hline
\end{tabular}

COLQ, collagen like tail subunit of asymmetric acetylcholinesterase; I, improved; NR, no response; W, worsened; P, pyridostigmine; N, neostigmine; $E_{1}$ ephedrine; D, 3,4-diaminopyridine; $S$, salbutamol; $A$, albuterol.

herself. She was able to make eye contact, smile socially, understand simple instructions, and point out what she wanted. However, she could speak only in monosyllables. Overall, at the age of 2 years, the patient's motor development was equivalent to approximately 10 months, although her cognitive and language abilities were relatively intact, at approximately 15 months.

Laboratory test results showed carbon dioxide retention on arterial gas analysis (68 $\mathrm{mm} \mathrm{Hg}$ [normal range, 35 to 45$]$ ) and increased ammonia level ( $155 \mu \mathrm{g} / \mathrm{dL}$ [normal range, 12 to 66$])$. Except these, laboratory test showed normal complete blood count and normal chemistry test including creatine kinase level (36 IU/L [normal range, 32 to 135]). Chest computed tomography, laryngoscopy, cardiac echocardiography, and cardiac magnetic resonance imaging (MRI) revealed no abnormalities, except a small atrial septal defect. Genetic tests for myotonic dystrophy, spinal muscular atrophy, Prader-Willi syndrome, and Williams syndrome were performed, and all reports were negative. The patient's beta- glucocerebrosidase level was assessed, and a metabolic workup was subsequently performed, including plasma amino acid, urine amino acid, serum lactic acid, and pyruvic acid. All test results were within the normal ranges, except those of serum lactic acid $(3.22 \mathrm{mmol} / \mathrm{L}$ [normal range, 0.5 to $2.2])$ and pyruvic acid $(0.167 \mathrm{mmol} / \mathrm{L}$ [normal range, 0.034 to $0.102]$ ). Electroencephalography and brain MRI were performed; however, no abnormalities were identified. She was subsequently referred to another hospital around her home for a follow-up.

At the age of 4 years, the patient was readmitted to our PICU due to respiratory failure. She showed delayed development, mus- cle weakness with no diurnal variation, and failure to thrive as well as mild ptosis with no diurnal variation and scoliosis with a Cobb angle of 51.0 degrees at T5-T9, which were not observed at the age of 2 years. We performed electromyography and nerve conduction velocity tests. Significant decremental response was observed in the $3-\mathrm{Hz}$ repetitive nerve stimulation test. Subsequently, next-generation sequencing of neuromuscular disease was performed, and the patient was diagnosed with COLQ-related CMS (compound heterozygous mutation in the COLQ gene, p.Arg315Ter and p.Arg236Ter) (Table 2).

After diagnosis, we began treatment with a salbutamol nebulizer ( $2.5 \mathrm{mg}$, twice per day) due to the absence of oral salbutamol and have maintained it for 2 years. Subsequently, her motor skills improved significantly. Her myasthenia gravis score improved from $7 / 39$ ( 1 month after salbutamol treatment) to $14 / 39$ (14 months after salbutamol treatment). In the 6-minute walking test performed, her walking distance was $130 \mathrm{~m}$, and she was able to walk for 5 minutes ( 4 months after salbutamol treatment). We rechecked the same test at 14 months after salbutamol treatment; her walking distance was $135 \mathrm{~m}$, and she could walk for 6 minutes. In particular, after beginning salbutamol treatment, she has not been admitted to our hospital and has not shown relapse or need for hospitalization in the PICU. Encouraged by these results, we increased the number of salbutamol treatments from two to four per day, and there have been no side effects so far.

To the best of our knowledge, this was the first reported case of the rare CMS in the Republic of Korea. When physicians encounter a patient with recurrent respiratory failure, they investigate the 
Table 2. Genetic and demographic characteristics of patient in our case

\begin{tabular}{|c|c|}
\hline Characteristic & Patient \\
\hline Age/age at presentation to the clinic (mo) & $71 / 24$ \\
\hline Age at diagnosis/follow-up time (mo) & $50 / 47$ \\
\hline Family history/consanguinity & $-1-$ \\
\hline Sex & Female \\
\hline Ethnic origin & Korea \\
\hline $\begin{array}{l}\text { Delayed motor milestones/jump/walk upstairs or downstairs in adult manner/3-word sentences/count } 1 \text { to } 10 \\
\text { (at the age of } 5 \text { years) }\end{array}$ & $+|+|-|-|+$ \\
\hline Facial deformity/ptosis/ophthalmoparesis/facial weakness/dysphagia & $+|+|+|+|-$ \\
\hline Respiratory crises & + \\
\hline $\begin{array}{l}\text { Slow pupillary light response/proximal weakness/distal muscle weakness/neck muscles weakness/scoliosis or } \\
\text { kyphosis }\end{array}$ & $\mathrm{ND} /+/+/+/+$ \\
\hline \multicolumn{2}{|l|}{ Electrophysiological studies } \\
\hline RNS decrement before salbutamol/after salbutamol treatment & $+/+$ \\
\hline Double CMAP & - \\
\hline Negative response to acetylcholinesterase inhibitors & + \\
\hline Mutations & COLO, p.Arg315Ter and p.Arg236Ter \\
\hline \multirow[t]{2}{*}{ Treatment (dose) } & Salbutamol nebulizer \\
\hline & ( $2.5 \mathrm{mg}$ twice up to 4 times per day) \\
\hline
\end{tabular}

+ , yes; -, no; ND, no data; RNS, repetitive nerve stimulation; CMAP, compound muscle action potential; COLQ, collagen like tail subunit of asymmetric acetylcholinesterase.

cause of the symptoms in the cardiovascular, pulmonary, and central nervous systems. However, as in our case, there may be other causes of recurrent respiratory failure. Because accurate diagnosis and appropriate evidence-based treatment can improve the quality of life in patients with CMS, we recommend that healthcare providers, specifically PICU physicians, consider recurrent respiratory failure as one of the clinical presentations of CMS and that they perform the relevant genetic evaluation. If COLQ-mutant CMS is confirmed, physicians should try to treat the patients using a salbutamol nebulizer.

This study was approved by the Yonsei University College of Medicine Institutional Review Board and the Research Ethics Committee of Severance Hospital (study approval number: 20193673-002). Written informed consent by the patients was waived due to a retrospective nature of our study.

\section{Conflicts of interest}

No potential conflict of interest relevant to this article was reported.

\section{ORCID}

Han Geul Kim, https://orcid.org/0000-0002-6415-9008

Se Hee Kim, https://orcid.org/0000-0001-7773-1942

\section{Author contribution}

Conceptualization: HGK and SHK. Data curation: HGK. Visualization: HGK and SHK. Writing-original draft: HGK. Writing-review \& editing: HGK, JSL, KWK, HCK, and SHK.

\section{References}

1. Gul Mert G, Ozcan N, Herguner O, Altunbasak S, Incecik F, Bisgin A, et al. Congenital myasthenic syndrome in Turkey: clinical and genetic features in the long-term follow-up of patients. Acta Neurol Belg 2019 Nov 26 [Epub]. https://doi. org/10.1007/s13760-019-01246-9.

2. Wadwekar V, Nair SS, Tandon V, Kuruvilla A, Nair M. Congenital myasthenic syndrome: ten years clinical experience from a quaternary care south-Indian hospital. J Clin Neurosci 2020; 72:238-43.

3. Guven A, Demirci M, Anlar B. Recurrent COLQ mutation in congenital myasthenic syndrome. Pediatr Neurol 2012;46:253-6.

4. Wargon I, Richard P, Kuntzer T, Sternberg D, Nafissi S, Gaudon $\mathrm{K}$, et al. Long-term follow-up of patients with congenital myasthenic syndrome caused by COLQ mutations. Neuromuscul Disord 2012;22:318-24.

5. Al-Shahoumi R, Brady LI, Schwartzentruber J, Tarnopolsky MA. Two cases of congenital myasthenic syndrome with vocal cord paralysis. Neurology 2015;84:1281-2. 